Article

\title{
Effectiveness of Prenyl Group on Flavonoids from Epimedium koreanum Nakai on Bacterial Neuraminidase Inhibition
}

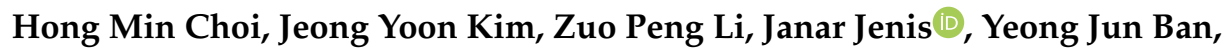 \\ Aizhamal Baiseitova and Ki Hun Park*
}

Division of Applied Life Science (BK21 plus), IALS, Gyeongsang National University, Jinju 52828, Korea; sgiantm@naver.com (H.M.C.); foryou6633@gmail.com (J.Y.K.); dameng@126.com (Z.P.L.); janarjenis@mail.ru (J.J.); banyoung972@naver.com (Y.J.B.); aizhabaiseitova@gmail.com (A.B.)

* Correspondence: khpark@gnu.ac.kr; Tel.: +82-772-1965; Fax: +82-772-1969

Academic Editor: Tiziano Tuccinardi

Received: 24 December 2018; Accepted: 13 January 2019; Published: 16 January 2019

\begin{abstract}
In this study, the inhibitory potential of bacterial neuraminidase (NA) was observed on the leaves of Epimedium koreanum Nakai, which is a popular ingredient in traditional herbal medicine. This study attempted to isolate the relevant, responsible metabolites and elucidate their inhibition mechanism. The methanol extraction process yielded eight flavonoids (1-8), of which compounds 7 and $\mathbf{8}$ were new compounds named koreanoside $F$ and koreanoside $G$, respectively. All the compounds (1-8) showed a significant inhibition to bacterial NA with $\mathrm{IC}_{50}$ values of $0.17-106.3 \mu \mathrm{M}$. In particular, the prenyl group on the flavonoids played a critical role in bacterial NA inhibition. Epimedokoreanin B (compound 1, $\mathrm{IC}_{50}=0.17 \mu \mathrm{M}$ ) with two prenyl groups on $\mathrm{C} 8$ and $\mathrm{C}^{\prime}$ of luteolin was 500 times more effective than luteolin $\left(\mathrm{IC}_{50}=85.6 \mu \mathrm{M}\right)$. A similar trend was observed on compound $2\left(\mathrm{IC}_{50}=0.68 \mu \mathrm{M}\right)$ versus dihydrokaempferol $\left(\mathrm{IC}_{50}=500.4 \mu \mathrm{M}\right)$ and compound $3\left(\mathrm{IC}_{50}=12.6 \mu \mathrm{M}\right)$ versus apigenin $\left(\mathrm{IC}_{50}=107.5 \mu \mathrm{M}\right)$. Kinetic parameters $\left(K_{\mathrm{m}}, V_{\max }\right.$, and $K_{\mathrm{ik}} / K_{\mathrm{iv}}$ ) evaluated that all the compounds apart from compound 5 showed noncompetitive inhibition. Compound 5 was proven to be a mixed type inhibitor. In an enzyme binding affinity experiment using fluorescence, affinity constants $\left(K_{S V}\right)$ were tightly related to inhibitory activities.
\end{abstract}

Keywords: Epimedium koreanum Nakai; koreanoside F; koreanoside G; bacterial neuraminidase; binding affinity

\section{Introduction}

The neuraminidases (EC 3.2.1.18) are enzymes that catalyze the hydrolysis of terminal neuraminic acid from a variety of glycoproteins and gangliosides. Bacterial neuraminidase (NA) preferentially cleaves $5-\mathrm{N}$-acetylneuraminic acid (Neu5Ac) from cell membrane glycoproteins via the linkage between neuraminic acid and $\alpha \rightarrow 3$ or $\alpha 2 \rightarrow 6$ galactose [1-3]. Bacterial neuraminidase is expressed among particular pathogens, such as Streptococcus pneumonia, Pseudomonas aeruginosa, and Clostridium perfringens, and it cleaves neuraminic acid from glycoconjugates. The key function of bacterial NA is to help promote mucosal infection via biofilm formation [4]. Chen et al. reported that bacterial NA inhibition blocks the desialylation of CD24 that occurring in sepsis, which preserves the Siglec inhibitory circuit and suppresses the inflammatory response. At the same time, bacterial NA acts with bacterial virulence, implicating biofilms formation and bacterial defense against antibiotics [5]. Consequently, bacterial NA implicated in numerous pathways involved in bacterial infection and its inhibitors will provide one of the ways to treat bacterial pathogenic diseases depending on the neuraminic acid hydrolysis [6]. Previously, our group has succeeded in isolating and characterizing 
the naturally occurring neuraminidase inhibitors, which are xanthones, pterocarpans, and geranylated flavonoids from Garcinia mangostana [7], Sophora flavescens [8], and Paulownia tomentosa [9].

Epimedium koreanum Nakai belongs to the Berberidaceae family and has a unique feature, having three branches and three leaves on each branch. It grows in Southeast Asian countries [10]. The aboveground parts of E. koreanum Nakai (leaves and stem) have been used as a medicinal herb for a general tonic against infertility, as well as against inflammatory diseases including cardiovascular diseases and arthritis [11,12]. Nowadays, the leaves are consumed as a popular medicinal herb. Its species continues to be a rich source of phenolic metabolites, of which prenylated flavonoids are the major constituents. Based on the composition of the phenolic metabolites, they display a broad spectrum of biological activities, such as antioxidative, anticancer, immunomodulatory, and neuroprotective functions [13,14].

In this study, we isolated eight prenylated flavonoids from using a methanol extraction process on the leaves of E. koreanum Nakai, and their structures were fully characterized by spectroscopic methods. All the isolated compounds were examined for bacterial NA inhibition and kinetic behavior. In particular, we observed a critical role of the prenyl group on the flavonoids in enzyme inhibition.

\section{Results and Discussion}

\subsection{Isolation of Flavonoids from E. koreanum Nakai}

In the preliminary screening, we observed that the ethyl acetate fraction of the methanol extract of E. koreanum Nakai leaves showed potent inhibition ( $80 \%$ inhibition at $50 \mu \mathrm{g} / \mathrm{mL}$ ) of bacterial neuraminidase (NA). The ethyl acetate fractions were purified over silica gel, C18 reversed-phase silica gel, and Sephadex LH-20 as described in Section 3.1 to find out the compounds responsible for the bacterial NA inhibition. The isolated compounds were identified as known prenylated flavonoids (1-6) and two new flavonoids, compounds 7 and 8. As shown in Figure 1, the flavonoids (compounds 1-6) were identified as epimedokoreanin B (compound 1), 8-( $\gamma, \gamma$-dimethyl allyl)-5,7, $4^{\prime}$-trihydroxydihydroflavonol (compound 2), 5,7,4'-trihydroxy-8,3'-diprenyl flavone (compound 3), icariside II (compound 4), icariin (compound 5), and sagittatoside B (compound 6).
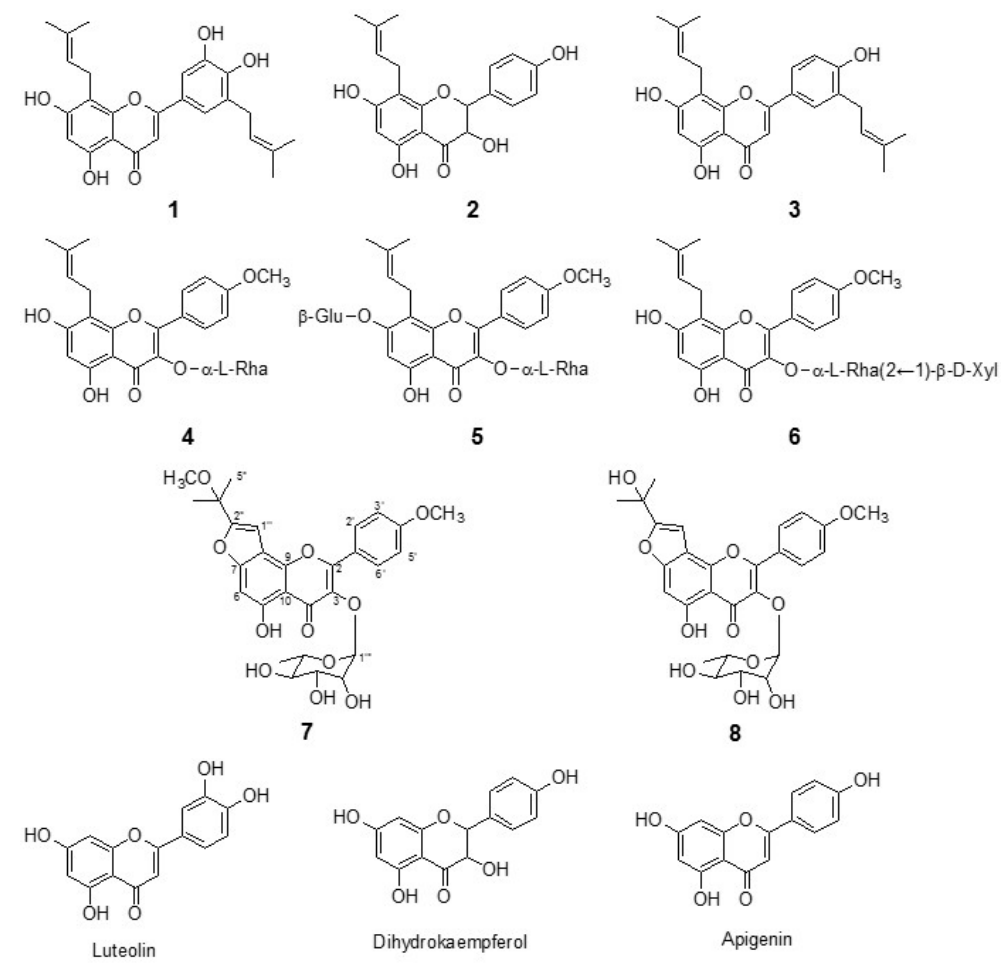

Figure 1. Chemical structures of flavonoids (1-8) from Epimedium koreanum Nakai. 
Compound 7 was isolated as a yellow powder with the molecular formula $\mathrm{C}_{28} \mathrm{H}_{31} \mathrm{O}_{11}$ by the $[\mathrm{M}+\mathrm{H}]^{+}$ion at 543.1906 (Calcd 543.1788) in HRFABMS. ${ }^{1} \mathrm{H}$ and ${ }^{13} \mathrm{C}-\mathrm{NMR}$ data in conjunction with DEPT experiments indicated the presence of 28 carbons consisting of the following functional groups: 6 methines $\left(\mathrm{sp}^{2}\right), 5$ methines $\left(\mathrm{sp}^{3}\right), 5$ methyls, and 12 quaternary carbons (Table 1 ). The analysis of 14 degrees of unsaturation indicated pentacyclic skeleton for compound 7. A typical flavonol skeleton was deduced by $\mathrm{C} 2(\delta \mathrm{c} 157.8), \mathrm{C} 3(\delta \mathrm{c} 135.9)$, and $\alpha, \beta$-unsaturated carbonyl group $(\delta \mathrm{c} 179.1)$. One set of $\mathrm{A}_{2} \mathrm{~B}_{2}$ resonance at $\delta_{\mathrm{H}} 7.04(2 \mathrm{H}, \mathrm{d}, J=8.7 \mathrm{~Hz})$ and $\delta_{\mathrm{H}}=7.88(2 \mathrm{H}, \mathrm{d}, J=8.7 \mathrm{~Hz})$ indicated the presence of a para substituted ring B. A strong $\mathrm{HMBC}$ correlation between $4^{\prime}-\mathrm{OCH}_{3}$ $\left(\delta_{\mathrm{H}} 3.81\right)$ and $\mathrm{C}-4^{\prime}(\delta \mathrm{c} 162.3)$ confirmed the location of the methoxy group. The prenyl-derived side chain was unveiled to be a 2-methoxydimethyl-furan moiety by the HMBC correlation of $\mathrm{H}-1 "\left(\delta_{\mathrm{H}} 6.93\right)$ with $\mathrm{C}-2 " \prime(\delta \mathrm{c} 159.1)$, as well as $\mathrm{CH}_{3}\left(\mathrm{C}^{\prime \prime}, \delta_{\mathrm{H}} 3.03\right)$ with $\mathrm{C}-3$ " $(\delta \mathrm{c} 73.3)$ and $\mathrm{C}-2$ " $(\delta \mathrm{c} 159.1)$. The methoxy group on $\mathrm{C}-3$ " was confirmed with a strong $\mathrm{HMBC}$ between $3^{\prime \prime}-\mathrm{CH}_{3} \mathrm{O}$ $\left(\delta_{\mathrm{H}} 3.03\right)$ and $\mathrm{C}-3^{\prime \prime}$. The furan moiety was placed on $\mathrm{C} 7$ and $\mathrm{C} 8$, because $\mathrm{H}-1^{\prime \prime}\left(\delta_{\mathrm{H}} 6.93, \mathrm{~s}\right)$ had a HMBC correlation with C-8 $(\delta \mathrm{c} 108.9)$ and C-9 $(\delta \mathrm{c} 158.2)$. Additionally, H-6 $\left(\delta_{\mathrm{H}} 6.78, \mathrm{~s}\right)$ was confirmed by the HMBC correlation of H-6 with C-5 $(\delta \mathrm{c} 159.5)$ and C-7 $(\delta \mathrm{c} 148.9)$. The rhamnose (Rha) moiety was clearly confirmed with $\mathrm{CH}_{3}\left(\delta_{\mathrm{H}} 0.82,3 \mathrm{H}, \mathrm{d}, J=5.8 \mathrm{~Hz}\right), \mathrm{H}-1\left(\delta_{\mathrm{H}} 5.38, \mathrm{~s}\right), \mathrm{H}-2\left(\delta_{\mathrm{H}} 3.19, \mathrm{~m}\right)$, $\mathrm{H}-3\left(\delta_{\mathrm{H}} 4.16, \mathrm{~m}\right), \mathrm{H}-4\left(\delta_{\mathrm{H}} 3.63, \mathrm{~m}\right), \mathrm{H}-5\left(\delta_{\mathrm{H}} 3.25, \mathrm{~m}\right)$, and H-6 $\left(\delta_{\mathrm{H}} 0.82, \mathrm{~d}, J=5.8 \mathrm{~Hz}\right)$. A clear HMBC correlation of anomeric $\mathrm{H}\left(\delta_{\mathrm{H}} 5.38\right)$ and C-3 $(\delta \mathrm{c} 135.9)$ indicated that rhamnose connected to $\mathrm{C}-3$. Simultaneously, the $\alpha$-configuration at the anomeric carbon was assigned on the basis of the coupling constant $(J<1 \mathrm{~Hz})$ (Table 1 and Figure 2). Thus, compound 7 was determined to be 5-hydroxy-2-(4-methoxyphenyl)-8-(2-methoxypropan-2-yl)-3-(((2S,3R,4R,5R,6S)-3,4,5-trihydroxy6-methyltetra-hydro-2H-pyran-2-yl)oxy)-4H-furo[2-3-h]chromen-4-one, named koreanoside F.

Table 1. ${ }^{1} \mathrm{H}-\mathrm{NMR}$ and ${ }^{13} \mathrm{C}-\mathrm{NMR}$ data of compounds 7 and 8 (500 MHz, MeOD).

\begin{tabular}{|c|c|c|c|c|}
\hline \multirow{2}{*}{ Position } & \multicolumn{2}{|l|}{7} & \multicolumn{2}{|l|}{8} \\
\hline & $\delta_{\mathrm{H}}$, mult, $(J, \mathrm{~Hz})$ & $\delta \mathrm{c}$ & $\delta_{\mathrm{H}}$, mult, $(J, \mathrm{~Hz})$ & $\delta \mathrm{c}$ \\
\hline 2 & - & 157.7 & - & 157.5 \\
\hline 3 & - & 135.9 & - & 135.8 \\
\hline 4 & - & 179.1 & - & 179.2 \\
\hline 5 & - & 159.5 & - & 157.8 \\
\hline 6 & $6.78, \mathrm{~s}$ & 94.2 & $6.90, \mathrm{~s}$ & 94.2 \\
\hline 7 & - & 148.9 & - & 148.9 \\
\hline 8 & - & 108.9 & - & 109.2 \\
\hline 9 & - & 158.2 & - & 158.9 \\
\hline 10 & - & 107.4 & - & 107.3 \\
\hline $1^{\prime}$ & - & 122.2 & - & 122.2 \\
\hline $2^{\prime}, 6^{\prime}$ & $7.88, \mathrm{~d},(J=8.7 \mathrm{~Hz})$ & 130.6 & $7.98, \mathrm{~d},(J=8.8 \mathrm{~Hz})$ & 130.5 \\
\hline $3^{\prime}, 5^{\prime}$ & $7.04, \mathrm{~d},(J=8.7 \mathrm{~Hz})$ & 113.9 & $7.15, \mathrm{~d},(J=8.8 \mathrm{~Hz})$ & 113.9 \\
\hline $4^{\prime}$ & - & 162.3 & - & 162.3 \\
\hline $1^{\prime \prime}$ & $6.93, \mathrm{~s}$ & 100.6 & $6.91, \mathrm{~s}$ & 96.9 \\
\hline $2^{\prime \prime}$ & - & 159.1 & - & 163.5 \\
\hline $3^{\prime \prime}$ & - & 73.3 & - & 68.2 \\
\hline $4^{\prime \prime}$ & $1.53, \mathrm{~s}$ & 24.4 & $1.66, \mathrm{~s}$ & 27.5 \\
\hline $5^{\prime \prime}$ & $1.53, \mathrm{~s}$ & 24.1 & $1.66, \mathrm{~s}$ & 27.5 \\
\hline $1^{\prime \prime \prime}$ & $5.38, \mathrm{~s}$ & 102.2 & $5.48, \mathrm{~s}$ & 102.2 \\
\hline $2^{\prime \prime \prime}$ & 3.19 , overlap & 70.5 & 3.30 , overlap & 70.5 \\
\hline $3^{\prime \prime \prime}$ & $4.16, \mathrm{~m}$ & 70.7 & $4.27, \mathrm{~d},(J=1.7 \mathrm{~Hz})$ & 70.7 \\
\hline $4^{\prime \prime \prime}$ & $3.63, \mathrm{~m}$ & 70.8 & $3.75, \mathrm{~m}$ & 70.8 \\
\hline $5^{\prime \prime \prime}$ & 3.25 , overlap & 71.7 & 3.37, overlap & 71.7 \\
\hline $6^{\prime \prime \prime}$ & $0.82, \mathrm{~d},(J=5.8 \mathrm{~Hz})$ & 16.3 & $0.93, \mathrm{~d},(J=5.90 \mathrm{~Hz})$ & 16.3 \\
\hline $3^{\prime \prime}-\mathrm{OCH}_{3}$ & $3.03, \mathrm{~s}$ & 49.9 & - & - \\
\hline $4^{\prime}-\mathrm{OCH}_{3}$ & $3.81, \mathrm{~s}$ & 54.6 & $3.93, \mathrm{~s}$ & 54.6 \\
\hline
\end{tabular}


Compound 8 was a yellow powder having molecular formula $\mathrm{C}_{27} \mathrm{H}_{28} \mathrm{O}_{11}$ and 14 degrees of unsaturation [HRFABMS $\left(m / z 529.1682[\mathrm{M}+\mathrm{H}]^{+}\right.$, Calcd 529.1632)]. The ${ }^{1} \mathrm{H}$ and ${ }^{13} \mathrm{C}-\mathrm{NMR}$ data of compound 8, fully assigned through 2D NMR experiments, closely resembled those of compound 7 (Table 1). Given the broad spectral similarities between this species and compound 7, we focused on identifying the furan moiety therein. The hydroxydimethyl group on the furan ring was confirmed by the $\mathrm{HMBC}$ correlation of $\mathrm{CH}_{3}\left(\mathrm{C}^{\prime \prime}, \delta_{\mathrm{H}} 1.66\right)$ with $\mathrm{C}-3^{\prime \prime}$ $(\delta \mathrm{c} 68.2)$ and C-2" ( $\delta \mathrm{c}$ 163.5) (Table 1 and Figure 2). Thus, compound 8 was determined to be 5-hydroxy-8-(2-hydroxypropan-2-yl)-2-(4-methoxyphenyl)-3-(( $2 \mathrm{~S}, 3 \mathrm{R}, 4 \mathrm{R}, 5 \mathrm{R}, 6 \mathrm{~S})-3,4,5$-trihydroxy6-methyl-tetrahydro-2H-pyran-2-yl)oxy)-4H-furo[2,3-h]chromen -4-one, named koreanoside G.

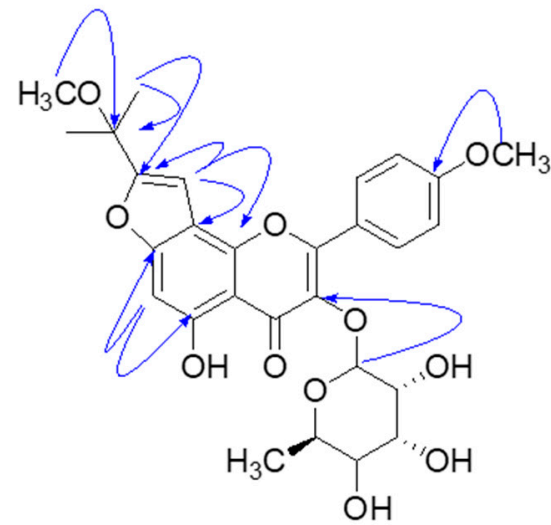

7

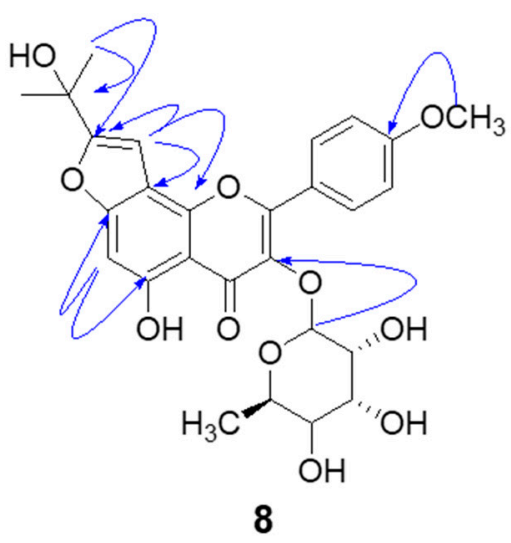

8

Figure 2. HMBC correlation $(\mathrm{H} \rightarrow \mathrm{C})$ of the new compounds 7 and 8.

\subsection{Bacterial Neuraminidase Inhibitory Activities}

The isolated prenylated flavonoids (1-8) were tested for enzymatic inhibitory activity against bacterial NA. The enzyme activity was assayed according to a standard literature procedure by following the hydrolysis of 4-methylumbeliferyl- $\alpha$-D- $N$-acetylneuraminic acid sodium salt hydrate [15]. The inhibitory profiles of the compounds (1-8) and three mother compounds (luteolin, dihydrokaempferol, and apigenin) are shown in Table 2. All the compounds (1-8) exhibited a potent bacterial NA inhibition with $\mathrm{IC}_{50}$ values of $0.17 \sim 106.3 \mu \mathrm{M}$.

Table 2. Inhibitory effects of the compounds (1-8) on bacterial neuraminidase activity.

\begin{tabular}{|c|c|c|}
\hline \multirow{2}{*}{ Compounds } & \multicolumn{2}{|c|}{ Bacterial Neuraminidase } \\
\hline & $\mathrm{IC}_{50}{ }^{1}(\mu \mathrm{M})$ & Kinetic Mode $\left(K_{\mathrm{i}}{ }^{2}, \mu \mathrm{M}\right)$ \\
\hline 1 & $0.17 \pm 0.02$ & Noncompetitive $(0.15 \pm 0.01)$ \\
\hline 2 & $0.68 \pm 0.03$ & Noncompetitive $(0.73 \pm 0.03)$ \\
\hline 3 & $12.6 \pm 0.2$ & Noncompetitive $(12.2 \pm 0.3)$ \\
\hline 4 & $20.0 \pm 0.5$ & Noncompetitive $(21.1 \pm 0.8)$ \\
\hline 5 & $57.8 \pm 1.1$ & Mixed type I (36.8 \pm 0.7$)$ \\
\hline 6 & $106.3 \pm 3.2$ & Noncompetitive $(103.2 \pm 1.4)$ \\
\hline 7 & $2.90 \pm 0.7$ & Noncompetitive $(2.73 \pm 0.6)$ \\
\hline 8 & $16.7 \pm 0.9$ & Noncompetitive $(16.4 \pm 0.9)$ \\
\hline Luteolin & $85.6 \pm 2.1$ & $\mathrm{NT}^{3}$ \\
\hline Dihydrokaempferol & $500.4 \pm 3.8$ & NT \\
\hline Apigenin & $107.5 \pm 1.8$ & NT \\
\hline Quercetin $^{4}$ & $20.2 \pm 0.8$ & NT \\
\hline
\end{tabular}

\footnotetext{
${ }^{1}$ All the compounds were examined in a set of experiments repeated three times; $\mathrm{IC}_{50}$ values of compounds represent the concentration that caused $50 \%$ enzyme activity loss. ${ }^{2}$ Values of inhibition constant. ${ }^{3}$ NT means not tested. ${ }^{4}$ Quercetin was used as a positive control.
} 
Three prenylated flavonoids (1-3) inhibited bacterial NA significantly with $\mathrm{IC}_{50}$ s of $0.17,0.68$, and $12.6 \mu \mathrm{M}$, respectively. They showed much better inhibition than the glycoside compounds (4-6). In particular, compound $\mathbf{1}\left(\mathrm{IC}_{50}=0.17 \mu \mathrm{M}\right)$, having two prenyl groups on $\mathrm{C} 8$ and $\mathrm{C}^{\prime}$ of luteolin, was 500 times more effective than the mother skeleton, luteolin $\left(\mathrm{IC}_{50}=85.6 \mu \mathrm{M}\right)$, as shown in Figure $3 \mathrm{a}$. Compound $2\left(\mathrm{IC}_{50}=0.68 \mu \mathrm{M}\right)$ was 700 times more potent in comparison with dihydrokaempferol $\left(\mathrm{IC}_{50}=500.4 \mu \mathrm{M}\right)$ (Figure 3b). The prenyl group effectiveness on bacterial NA inhibition was also observed between compound $3\left(\mathrm{IC}_{50}=12.6 \mu \mathrm{M}\right)$ and apigenin $\left(\mathrm{IC}_{50}=107.5 \mu \mathrm{M}\right)$ (Figure 3c). Taken together, the prenyl group on the flavonoids played a critical role in bacterial NA inhibition. The two new compounds (7 and 8) also exhibited potent inhibition with $\mathrm{IC}_{50} \mathrm{~s}$ of $2.9 \mu \mathrm{M}$ and $16.7 \mu \mathrm{M}$, respectively. Particularly, the structural differences between compounds $\mathbf{7}$ and $\mathbf{8}$ was in the presence of the methoxy group or hydroxyl group on C-2", but the methoxy group (7) was 5 times more effective compared with the hydroxyl group (8).

(a)

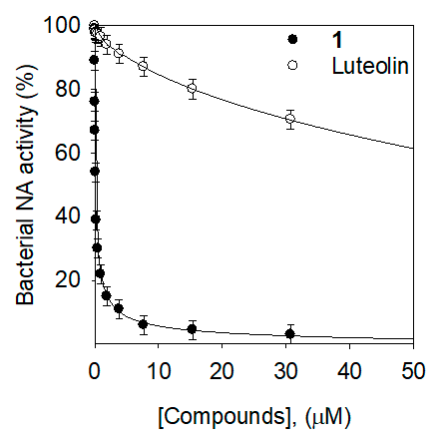

(b)

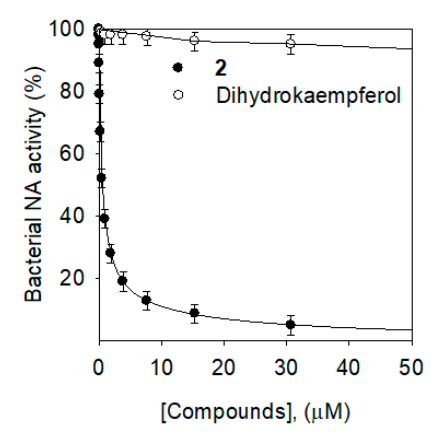

(c)

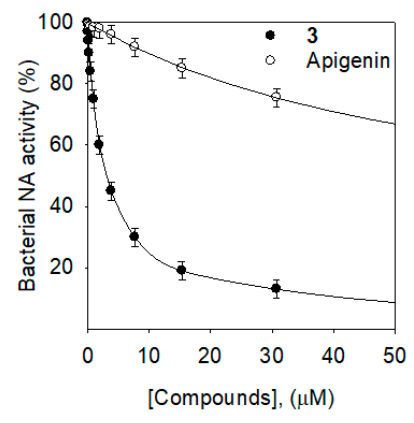

Figure 3. Effectiveness of the prenyl group on the bacterial neuraminidase inhibitory activity. (a) compound 1 versus luteolin, (b) compound 2 versus dihydrokaempferol, and (c) compound 3 versus apigenin.

In the kinetic analysis of the inhibitors, all of the compounds manifested the same relationship between enzyme activity and enzyme concentration. All the compounds inhibited the bacterial NA enzyme dose-dependently. The inhibition of bacterial NA by compound $\mathbf{1}$ (the most effective species) is illustrated in Figure 4a, representatively. On the plots of the initial velocity versus the enzyme concentration in the presence of different concentrations of compound 1, increasing the inhibitor concentrations resulted in the lowering of the slope of line. All of the straight lines passed through the origin, indicating that this compound was a reversible inhibitor (Figure $4 b$ ).

(a)

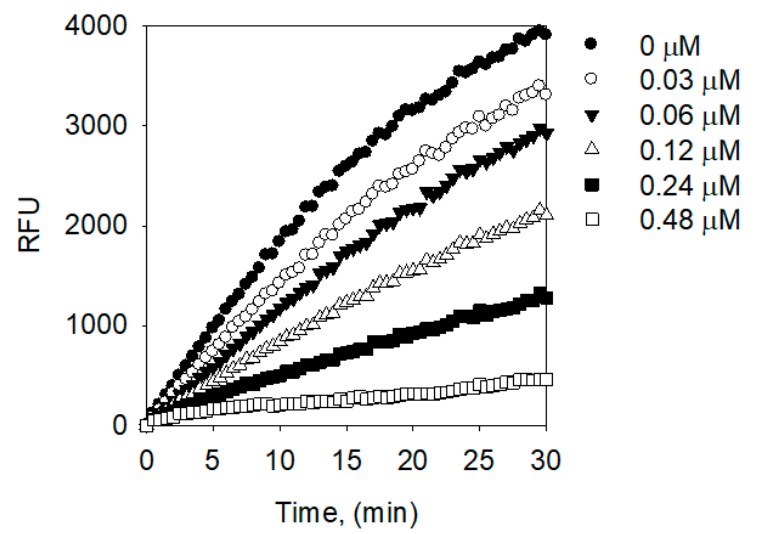

(b)

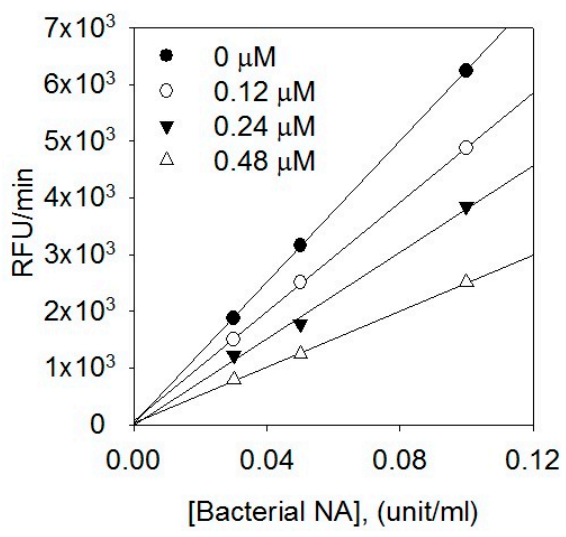

Figure 4. (a) Dose-dependent inhibition of bacterial neuraminidase inhibitory effects by compound 1, and (b) Determination of the reversible inhibitory mechanism of compound $\mathbf{1}$. 
The enzyme inhibition properties of compounds 1-8 were modeled using double-reciprocal plots of Lineweaver-Burk and Dixon plots. As shown in Figure 5a, the analysis of compound 1 exhibited that $V_{\max }$ decreased without changing $K_{\mathrm{m}}$ in the presence of the increasing concentration of the inhibitor. As can be seen in the graph (Figure 5$),-1 / K_{\mathrm{m}}$ (the $x$-intercept) was unaffected by the concentration, whereas $1 / V_{\max }$ became more positive. This behavior indicates that compound 1 exhibits noncompetitive inhibition characteristics for NA. The $K_{\mathrm{i}}$ value of compound $\mathbf{1}$ was calculated as $0.15 \mu \mathrm{M}$ by Dixon plots (Figure $5 \mathrm{~b}$ ). Similar trends can also be observed in all the compounds bearing sugar moieties on both $A$ and $C$ rings, apart from compound 5 . A similar analysis of compound 5 showed a series of lines, which intercept to the left of the vertical axis and above the horizontal axis, indicating that compound 5 was a mixed-type inhibitor (Figure $5 \mathrm{c}$ ). The $K_{\mathrm{i}}$ value was estimated as $36.8 \mu \mathrm{M}$ by Dixon plots (Figure $5 \mathrm{~d}$ ).

(a)

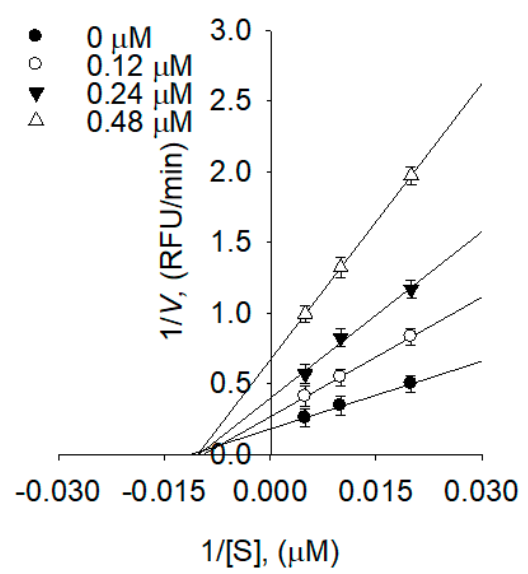

(c)

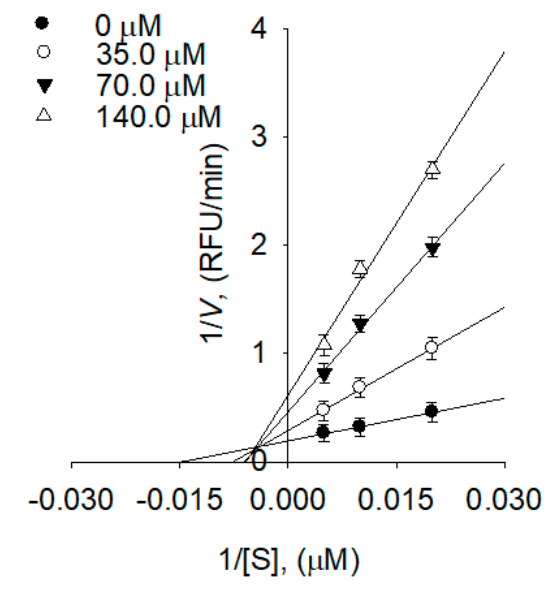

(b)

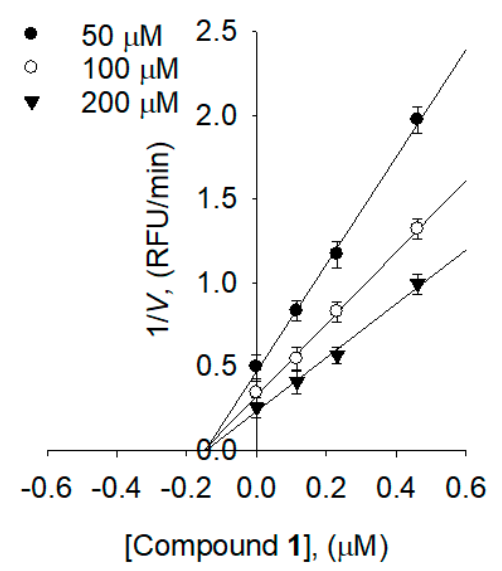

(d)

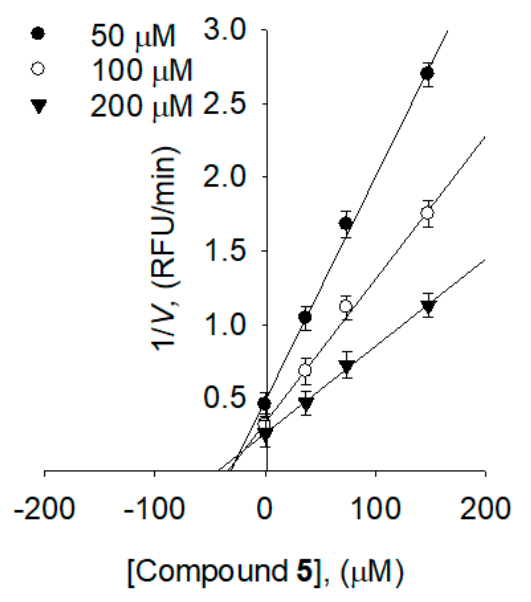

Figure 5. Bacterial neuraminidase kinetics of compounds $\mathbf{1}$ and 5 using 4-methylumbeliferyl$\alpha$-D-N-acetylneuraminic acid sodium salt hydrate. (a) Lineweaver-Burk plots of compound 1, (b) Dixon plots of compound 1, (c) Lineweaver-Burk plots of compound 5, and (d) Dixon plots of compound 5.

To further confirm noncompetitive and mixed-type behavior, the results were applied to Yang's method (Table 3) [16]. In this procedure, $K_{\mathrm{m}}$ and $V_{\max }$ are plotted against the inhibitor concentration. The new kinetic constant $K_{\mathrm{ik}}$ can be fitted to Equation (1), while $K_{\mathrm{iv}}$ can be fitted to Equation (2). From the results of the fit, the $K_{\mathrm{ik}} / K_{\mathrm{iv}}$ ratio were between 6.68 and 16.04 for compound $\mathbf{1}$, which is further consistent with noncompetitive behavior. Compound 5 showed typical mixed-type behavior with $2.02 \sim 3.66$ of $K_{\mathrm{ik}} / K_{\mathrm{iv}}[16]$. 
Table 3. Effect of different concentrations of compounds 1 and 5 on $V_{\max }, K_{\mathrm{m}}$, and the $K_{\mathrm{ik}} / K_{\mathrm{iv}}$ ratio using bacterial neuraminidase.

\begin{tabular}{ccccc}
\hline Compounds & {$[\mathbf{I}],(\mu \mathbf{M})$} & $V_{\max }{ }^{1}$ & $\boldsymbol{K}_{\mathrm{m}}{ }^{2}$ & $\boldsymbol{K}_{\mathbf{i k}} / \boldsymbol{K}_{\mathbf{i v}}{ }^{3}$ \\
\hline $\mathbf{1}$ & 0 & 5.531 & 107.4564 & - \\
- & 0.12 & 2.738 & 105.2853 & 16.0415 \\
- & 0.24 & 2.513 & 98.6856 & 6.6846 \\
- & 0.48 & 1.494 & 97.3510 & 7.7610 \\
$\mathbf{5}$ & 0 & 5.1813 & 120.1982 & - \\
- & 35.0 & 3.4578 & 131.0961 & 3.6688 \\
- & 70.0 & 2.1692 & 150.0805 & 2.3384 \\
- & 140.0 & 1.6200 & 161.0846 & 2.0207 \\
\hline
\end{tabular}

${ }^{1} V_{\max }$ is the maximal velocity of the enzyme assay. ${ }^{2} K_{\mathrm{m}}$ is the Michaelis-Menten constant. ${ }^{3}$ The $K_{\mathrm{ik}} / K_{\mathrm{iv}}$ ratio is a rate constant according to Yang's method [16].

\subsection{Binding Affinities between Bacterial Neuraminidase and Compounds}

Proteins have intrinsic fluorescence mainly due to tryptophan (Trp), tyrosine (Tyr), and phenylalanine (Phe) residues [17]. The intrinsic fluorescence of the protein often changes as a function of the ligand concentrations. We investigated the enzyme binding affinities of the inhibitors on bacterial NA by a fluorescence quenching (FQ) effect. Bacterial neuraminidase has three fluorescent residues, eight $\operatorname{Trp}(31,80,118,124,135,149,172,217$, and 264), $22 \operatorname{Tyr}(35,57,65,82,95,141,203,204$, $209,246,248,251,255,267,310,318,336,347,361,369,376$, and 377), and eight Phe (8, 24, 36, 52, 76, 286, 322 , and 352) [18]. There was no significant emission from any of the other components of the assay mixture under the measurement condition (i.e., emission from 300 to $400 \mathrm{~nm}$ ). The binding affinity $\left(K_{\mathrm{SV}}\right)$ was analyzed using the Stern-Volmer Equation (Equation (3)). Figure 6 shows typical Stern-Volmer plots of compounds 1, 2, and dihydrokaempferol on bacterial NA. Evidently, the fluorescence intensities were dramatically decreased for the best performing inhibitors $\mathbf{1}\left(\mathrm{IC}_{50}=0.17 \mu \mathrm{M}\right), \mathbf{2}\left(\mathrm{IC}_{50}=0.68 \mu \mathrm{M}\right)$, proportional to the increasing of the concentration. The FQ effect of the lowest active compound (dihydrokaempferol, $\mathrm{IC}_{50}=500.4 \mu \mathrm{M}$ ) was insignificant. The FQ effects of the remaining compounds are displayed in Table 4 and the Supplementary Materials. The binding affinities of the Stern-Volmer constants $\left(K_{\mathrm{SV}}\right)$ of inhibitors could be ranked in the following order $1>2>3>4$, which is in agreement with the order of their inhibition potencies $\left(\mathrm{IC}_{50} \mathrm{~s}\right)$ as shown in Figure $6 \mathrm{~d}$. The binding constant $\left(K_{\mathrm{A}}\right)$ and the number of binding sites $(n)$ were calculated by Equation (4). The binding constants $\left(K_{\mathrm{A}}\right)$ were also correlated with inhibitory potencies $\left(\mathrm{IC}_{50} \mathrm{~s}\right)$ as shown in Table 4 .

Table 4. Fluorescence quenching effects of the isolated compounds (1-8) and their parent compounds (luteolin, dihydrokaempferol, and apigenin) on the bacterial neuraminidase.

\begin{tabular}{|c|c|c|c|c|c|}
\hline Compounds & $\begin{array}{c}K_{\mathrm{SV}} \\
\left(\times 10^{5} \mathrm{~L} \cdot \mathrm{mol}^{-1}\right)\end{array}$ & $\mathbf{R}^{2}$ & $\begin{array}{c}K_{\mathrm{A}} \\
\left(\times 10^{6} \mathrm{~L} \cdot \mathrm{mol}^{-1}\right)\end{array}$ & $n$ & $\mathbf{R}^{2}$ \\
\hline 1 & 4.1104 & 0.9886 & 0.9666 & 1.6920 & 0.9917 \\
\hline 2 & 2.3636 & 0.9843 & 0.7923 & 1.1974 & 0.9933 \\
\hline 3 & 1.3442 & 0.9997 & 0.7604 & 1.1206 & 0.9915 \\
\hline 4 & 0.9569 & 0.9989 & 0.7335 & 1.0917 & 0.9998 \\
\hline 5 & 0.6040 & 0.9920 & 0.5844 & 0.8147 & 0.9955 \\
\hline 6 & 0.5608 & 0.9875 & 0.5057 & 0.7006 & 0.9998 \\
\hline 7 & 2.1656 & 0.9895 & 0.7851 & 1.1733 & 0.9955 \\
\hline 8 & 1.1120 & 0.9904 & 0.7416 & 1.0868 & 0.9986 \\
\hline Luteolin & 0.5614 & 0.9986 & 0.5578 & 0.7662 & 0.9998 \\
\hline Dihydrokaempferol & 0.2479 & 0.9959 & 0.2998 & 0.5758 & 0.9986 \\
\hline Apigenin & 0.4481 & 0.9926 & 0.5142 & 0.4481 & 0.9993 \\
\hline
\end{tabular}


(a)

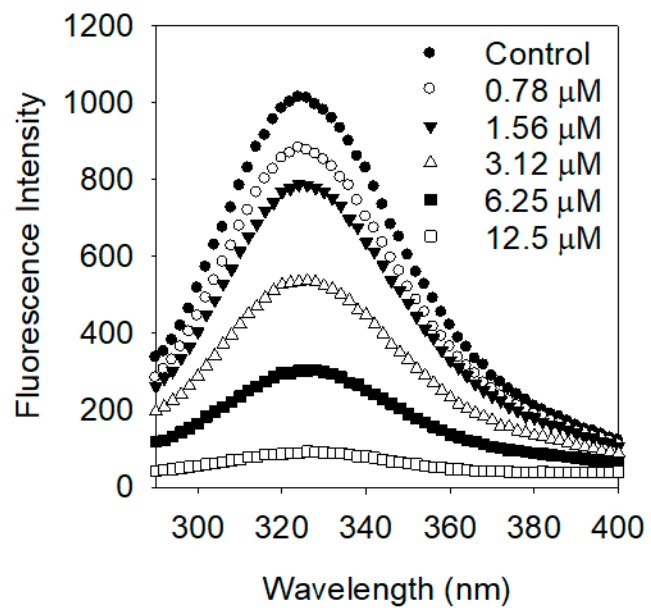

(c)

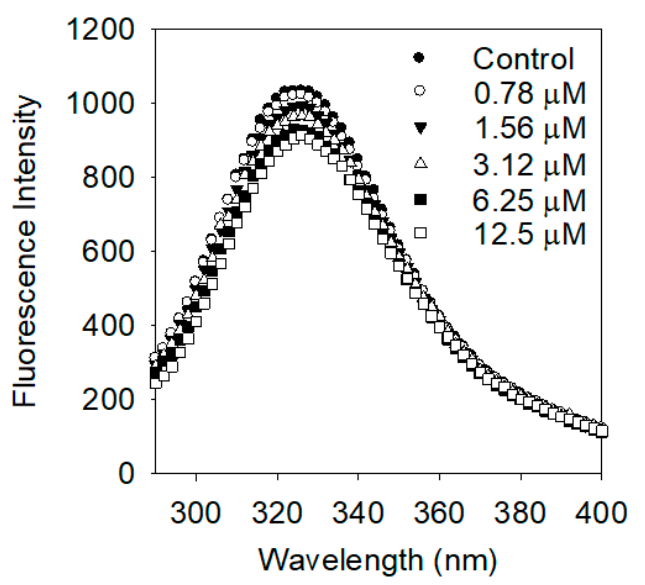

(b)

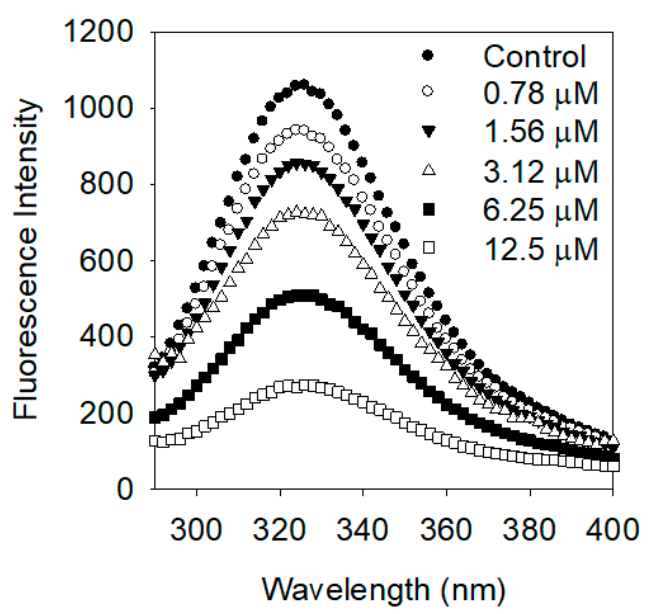

(d)

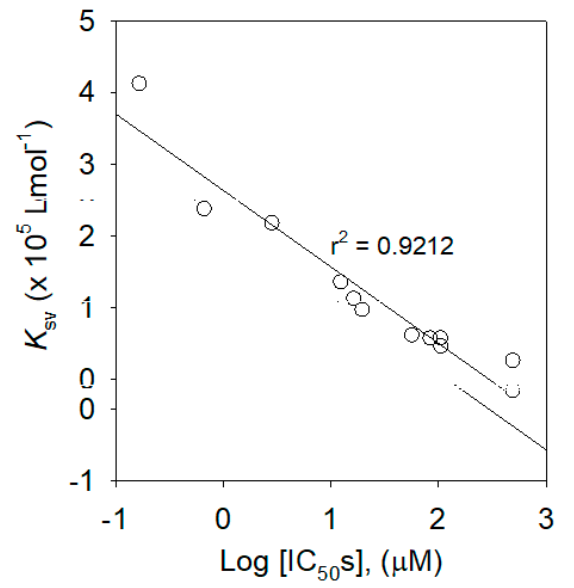

Figure 6. The effects of (a) compound 1, (b) compound 2, (c) dihydrokaempferol on the fluorescence emission spectra of bacterial neuraminidase, and (d) the correlation between the inhibitory potencies $\left(\mathrm{IC}_{50} \mathrm{~s}\right)$ and the Stern-Volmer constant $\left(K_{\mathrm{SV}}\right)$.

\section{Materials and Methods}

\subsection{Chemicals and Materials}

The organic solvents used for isolation were of first grade. Water, methanol, acetonitrile, and acetic acid of analytical grade for HPLC and MPLC were purchased from Fisher (Fisher Scientific, Hampton, NH, USA). Open column chromatography was carried out using silica gel (230-400 mesh, Merck, Kenilworkth, NJ, USA), C-18S (12 nm, S-20 $\mu \mathrm{m}$, YMC, Kyoto, Japan), and Sephadex LH-20 (GE Healthcare Life Sciences, Chicago, IL, USA). Triart C18 (S-5 $\mu \mathrm{m}, 12 \mathrm{~nm}$ and S-10 $\mu \mathrm{m}, 12 \mathrm{~nm}$, YMC, Kyoto, Japan) was used for recycle HPLC and MPLC. The enzyme assay was carried out with neuraminidase from Clostridium perfringens (EC 3.2.1.18) (Sigma Aldrich Co., St. Louis, MO, USA). E. koreanum Nakai leaves $(1.8 \mathrm{~kg}$ ) permitted by Korea Food and Drug Administration (KFDA) were purchased from a local market.

\subsection{Instruments}

The UV spectra were measured in Spectra Max M3 Multi-Mode Microplate Reader (Molecular Devise, Sunnyvale, CA, USA). ${ }^{1} \mathrm{H}$ and ${ }^{13} \mathrm{C}-\mathrm{NMR}$, as well as 2D NMR data, were obtained on a Bruker AM 500 spectrometer (Bruker, Karlsruhe, Germany). High-resolution fast atom bombardment mass (HRFABMS) spectra were obtained on a JEOL JMS-700 instrument (JEOL Ltd., Akishima, Japan). MPLC 
was conducted on a Forte/R 100 (YMC Co., Ltd., Kyoto, Japan) and recycle HPLC was conducted on a LC-9130G NEXT (JAI Co., Ltd., Tokyo, Japan).

\subsection{Extraction and Isolation}

The dried leaves of E. koreanum Nakai $(0.5 \mathrm{~kg})$ were extracted using methanol (10 l) at room temperature for 1 week to obtain a crude extract $(48 \mathrm{~g})$. The crude extract was suspended in water and successively partitioned into ethyl acetate to afford a dark residue (18 g). The ethyl acetate fraction (15 g) was subjected to column chromatography on silica gel $(8 \times 40 \mathrm{~cm}, 500 \mathrm{~g})$ and eluted with a gradient flow of $n$-hexane/ethyl acetate (20:1 to 1:2, $v / v$ ) to give 20 fractions (A1-A20, each $200 \mathrm{~mL}$ ). The fractions A8-15 (6.8 g) were fractionated via Forte-R MPLC $(250 \times 20.0 \mathrm{~mm}, \mathrm{C} 18-\mathrm{S}, \mathrm{S}-10 \mu \mathrm{m}$, $12 \mathrm{~nm}, \mathrm{YMC}$ ) eluting with a gradual increase in $\mathrm{MeOH}(0-100 \%)$ to afford 50 subfractions (B1-B50, 20 $\mathrm{mL}$ each). The above MPLC process was repeated with $0.5 \mathrm{~g}$ each time. Subfractions B12-16 (1.8 g) enriched with compounds 4-8 were further chromatographed over LC-9130G NEXT recycle HPLC $(250 \times 20.0 \mathrm{~mm}, \mathrm{C} 18-\mathrm{S}, \mathrm{S}-5 \mu \mathrm{m}, 12 \mathrm{~nm}, \mathrm{YMC}$, Kyoto, Japan), eluted with a gradual increase in MeOH $(0-100 \%)$. This recycle HPLC was repeated to afford compounds $4(22 \mathrm{mg}), 5(18 \mathrm{mg})$, and $6(21 \mathrm{mg})$. The mixture enriched with compounds 7 and 8 was purified by Sephadex LH-20 with eluting MeOH to obtain the compounds 7 (10 mg) and 8 (12 mg). Similarly, subfractions B17-21 (1.1 g), enriched with compounds 1-3, were used in the recycle HPLC to yield compounds $\mathbf{1}(11 \mathrm{mg}), \mathbf{2}(16 \mathrm{mg})$, and $\mathbf{3}(8 \mathrm{mg})$. All the isolated compounds were identified on the basis of spectroscopic data and comparisons with previous studies (Supplementary Materials) $[15,19,20]$.

\subsubsection{Epimedokoreanin B (Compound 1)}

EIMS $\mathrm{m} / \mathrm{z} 422$ [M] ${ }^{+}$; HREIMS $\mathrm{m} / \mathrm{z} 422.1721$ (Calcd for $\mathrm{C}_{25} \mathrm{H}_{26} \mathrm{O}_{6}, 422.1729$ ); pale yellow powder; ${ }^{1} \mathrm{H}-\mathrm{NMR}(500 \mathrm{MHz}, \mathrm{MeOD}) ; \delta_{\mathrm{H}} 1.57\left(3 \mathrm{H}, \mathrm{d}, J=0.8 \mathrm{~Hz}, \mathrm{H}-5^{\prime \prime}\right), 1.64\left(3 \mathrm{H}, \mathrm{s}, \mathrm{H}-5^{\prime \prime \prime}\right), 1.66(3 \mathrm{H}, \mathrm{d}, J=0.9$ $\left.\mathrm{Hz}, \mathrm{H}-4^{\prime \prime}\right), 1.69$ (3H, s, H-4'"'), 3.25 (2H, d, J = 7.3 Hz, H-1"'), $3.40\left(2 \mathrm{H}, \mathrm{d}, J=7.1 \mathrm{~Hz}, \mathrm{H}-1^{\prime \prime \prime}\right), 5.18(1 \mathrm{H}, \mathrm{m}$, H-2"), $5.24\left(1 \mathrm{H}, \mathrm{dddd}, J=7.4,6.0,2.8,1.4 \mathrm{~Hz}, \mathrm{H}-2^{\prime \prime \prime}\right), 6.13(1 \mathrm{H}, \mathrm{s}, \mathrm{H}-6), 6.36(1 \mathrm{H}, \mathrm{s}, \mathrm{H}-3), 7.13(1 \mathrm{H}, \mathrm{d}$, $\left.J=2.1 \mathrm{~Hz}, \mathrm{H}-2^{\prime}\right), 7.21\left(1 \mathrm{H}, \mathrm{d}, J=2.2 \mathrm{~Hz}, \mathrm{H}-6^{\prime}\right)$.

\subsubsection{8-( $\gamma, \gamma$-Dimethyl allyl)-5,7,4'-trihydroxydihydroflavonol (Compound 2)}

EIMS $m / z 356$ [M] ${ }^{+}$; HREIMS $m / z 356.1262$ (Calcd for $\mathrm{C}_{20} \mathrm{H}_{20} \mathrm{O}_{6}, 356.1260$ ); yellow powder; ${ }^{1} \mathrm{H}-\mathrm{NMR}(500 \mathrm{MHz}, \mathrm{MeOH}) ; \delta_{\mathrm{H}} 1.40\left(3 \mathrm{H}, \mathrm{s}, \mathrm{H}-5^{\prime \prime}\right), 1.50\left(3 \mathrm{H}, \mathrm{s}, \mathrm{H}-4^{\prime \prime}\right), 3.03\left(2 \mathrm{H}, \mathrm{s}, \mathrm{H}-1^{\prime \prime}\right), 4.39$ (1H, s, $\mathrm{H}-3), 4.82(1 \mathrm{H}, \mathrm{s}, \mathrm{H}-2), 5.01\left(1 \mathrm{H}, \mathrm{s}, \mathrm{H}-2^{\prime \prime}\right), 6.74\left(2 \mathrm{H}, \mathrm{d}, J=8.6 \mathrm{~Hz}, \mathrm{H}-3^{\prime}\right.$ and $\left.\mathrm{H}-5^{\prime}\right), 7.26(2 \mathrm{H}, \mathrm{d}, J=8.5 \mathrm{~Hz}$, $\mathrm{H}-2^{\prime}$ and $\left.\mathrm{H}-6^{\prime}\right), 8.87(1 \mathrm{H}, \mathrm{s}, \mathrm{H}-6)$.

\subsubsection{5,7, $4^{\prime}$-Trihydroxy-8,3'-diprenylflavone (Compound 3)}

EIMS $m / z 406$ [M] ${ }^{+}$; HREIMS $m / z 406.1784$ (Calcd for $\mathrm{C}_{25} \mathrm{H}_{26} \mathrm{O}_{5}, 406.1780$ ); white powder; ${ }^{1} \mathrm{H}-\mathrm{NMR}(500 \mathrm{MHz}, \mathrm{MeOH}) ; \delta_{\mathrm{H}} 1.56\left(3 \mathrm{H}, \mathrm{s}, \mathrm{H}-5^{\prime \prime \prime}\right), 1.62\left(3 \mathrm{H}, \mathrm{s}, \mathrm{H}-5^{\prime \prime}\right), 1.66\left(3 \mathrm{H}, \mathrm{s}, \mathrm{H}-4^{\prime \prime \prime}\right), 1.68(3 \mathrm{H}, \mathrm{s}$, H-4" $), 3.22\left(2 \mathrm{H}, \mathrm{s}, \mathrm{H}-1^{\prime \prime}\right), 3.34\left(2 \mathrm{H}, \mathrm{d}, J=6.9 \mathrm{~Hz}, \mathrm{H}-1^{\prime \prime \prime}\right), 5.13\left(1 \mathrm{H}, \mathrm{t}, J=6.9 \mathrm{~Hz}, \mathrm{H}-2^{\prime \prime \prime}\right), 5.22(1 \mathrm{H}, \mathrm{t}, J=7.4$ $\left.\mathrm{Hz}, \mathrm{H}-2^{\prime \prime}\right), 6.10(1 \mathrm{H}, \mathrm{s}, \mathrm{H}-6), 6.34(1 \mathrm{H}, \mathrm{s}, \mathrm{H}-3), 6.74\left(1 \mathrm{H}, \mathrm{d}, J=8.3 \mathrm{~Hz}, \mathrm{H}-3^{\prime}\right), 7.48\left(1 \mathrm{H}, \mathrm{d}, J=6.5 \mathrm{~Hz}, \mathrm{H}-2^{\prime}\right)$, $7.55\left(1 \mathrm{H}, \mathrm{d}, J=2.1 \mathrm{~Hz}, \mathrm{H}-6^{\prime}\right)$.

\subsubsection{Icariside II (Compound 4)}

FABMS $m / z 515$ [M] $]^{+}$; HRFABMS $\mathrm{m} / \mathrm{z} 515.1893$ (Calcd for $\mathrm{C}_{27} \mathrm{H}_{30} \mathrm{O}_{10}, 515.1839$ ); pale yellow powder; ${ }^{1} \mathrm{H}-\mathrm{NMR}(500 \mathrm{MHz}, \mathrm{MeOH}) ; \delta_{\mathrm{H}} 0.92\left(3 \mathrm{H}, \mathrm{d}, J=6.0 \mathrm{~Hz}, \mathrm{H}-6^{\prime \prime \prime}\right), 1.68\left(3 \mathrm{H}, \mathrm{s}, \mathrm{H}-5^{\prime \prime}\right), 1.73(3 \mathrm{H}, \mathrm{s}$, H-4" $), 3.29\left(1 \mathrm{H}, \mathrm{dd}, J=9.6,6.0 \mathrm{~Hz}, \mathrm{H}-4^{\prime \prime \prime}\right), 3.34\left(2 \mathrm{H}, \mathrm{dd}, J=20.5,6.8 \mathrm{~Hz}, \mathrm{H}-1^{\prime \prime}\right), 3.36\left(1 \mathrm{H}, \mathrm{m}, \mathrm{H}-5^{\prime \prime \prime}\right), 3.73$ $\left(1 \mathrm{H}, \mathrm{dd}, \mathrm{H}-3^{\prime \prime \prime}\right), 3.91\left(3 \mathrm{H}, \mathrm{s}, \mathrm{H}-7^{\prime}\right), 4.24\left(1 \mathrm{H}, \mathrm{d}, J=1.4 \mathrm{~Hz}, \mathrm{H}-2^{\prime \prime \prime}\right), 5.21\left(1 \mathrm{H}, \mathrm{t}, J=6.9 \mathrm{~Hz}, \mathrm{H}-2^{\prime \prime}\right), 5.46(1 \mathrm{H}$, ddd, $\left.J=35.2,14.8,7.0 \mathrm{~Hz}, \mathrm{H}-1^{\prime \prime \prime}\right), 6.28(1 \mathrm{H}, \mathrm{s}, \mathrm{H}-6), 7.10\left(2 \mathrm{H}, \mathrm{d}, J=8.8 \mathrm{~Hz}, \mathrm{H}-3^{\prime}\right.$ and $\left.\mathrm{H}-5^{\prime}\right), 7.89(2 \mathrm{H}, \mathrm{d}$, $J=8.8 \mathrm{~Hz}, \mathrm{H}-2^{\prime}$ and $\left.\mathrm{H}-6^{\prime}\right)$. 


\subsubsection{Icariin (Compound 5)}

FABMS $m / z 677$ [M] ${ }^{+}$; HRFABMS $m / z 677.2460$ (Calcd for $\mathrm{C}_{33} \mathrm{H}_{40} \mathrm{O}_{15}, 677.2367$ ); pale yellow powder; ${ }^{1} \mathrm{H}-\mathrm{NMR}(500 \mathrm{MHz}, \mathrm{DMSO}) ; \delta_{\mathrm{H}} 0.79\left(3 \mathrm{H}, \mathrm{d}, J=6.03, \mathrm{H}-6^{\prime \prime \prime}\right), 1.60\left(3 \mathrm{H}, \mathrm{s}, \mathrm{H}-5^{\prime \prime}\right), 1.69$ (3H, s, H-4"), 3.20-3.02 (3H, m, H-4"' ), 3.20-3.02 (3H, m, H-4"'"), 3.20-3.02 (3H, m, H-5"'"), 3.31-3.27 (2H, $\left.\mathrm{m}, \mathrm{H}-2^{\prime \prime \prime}\right), 3.31-3.27\left(2 \mathrm{H}, \mathrm{m}, \mathrm{H}-3^{\prime \prime \prime}\right), 3.43-3.40\left(2 \mathrm{H}, \mathrm{m}, \mathrm{H}-5^{\prime \prime \prime}\right), 3.48\left(1 \mathrm{H}, \mathrm{dd}, J=5.81,11.73 \mathrm{~Hz}, \mathrm{H}-3^{\prime \prime \prime \prime}\right)$, $3.57\left(1 \mathrm{H}, \mathrm{dd}, J=7.46,14.56 \mathrm{~Hz}, \mathrm{H}-1^{\prime \prime}\right), 3.71\left(1 \mathrm{H}, \mathrm{dd}, J=10.2,5.3 \mathrm{~Hz}, \mathrm{H}-6^{\prime \prime \prime}\right), 3.86\left(3 \mathrm{H}, \mathrm{s}, \mathrm{H}-7^{\prime}\right), 4.00(1 \mathrm{H}, \mathrm{t}$, $\left.J=4.44 \mathrm{~Hz}, \mathrm{H}-2^{\prime \prime \prime}\right), 4.99\left(1 \mathrm{H}, \mathrm{d}, J=4.41 \mathrm{~Hz}, \mathrm{H}-1^{\prime \prime \prime}\right), 5.28\left(1 \mathrm{H}, \mathrm{d}, J=1.45 \mathrm{~Hz}, \mathrm{H}-1^{\prime \prime \prime}\right), 6.63(1 \mathrm{H}, \mathrm{s}, \mathrm{H}-6)$, $7.13\left(2 \mathrm{H}, \mathrm{d}, J=9.0 \mathrm{~Hz}, \mathrm{H}-3^{\prime}\right.$ and $\left.\mathrm{H}-5^{\prime}\right), 7.89\left(2 \mathrm{H}, \mathrm{d}, J=8.9 \mathrm{~Hz}, \mathrm{H}-2^{\prime}\right.$ and $\left.\mathrm{H}-6^{\prime}\right)$.

\subsubsection{Sagittatoside B (Compound 6)}

FABMS $m / z 647[\mathrm{M}]^{+}$; HRFABMS $m / z 647.2369$ (Calcd for $\mathrm{C}_{32} \mathrm{H}_{38} \mathrm{O}_{14}, 647.2262$ ); pale yellow powder; ${ }^{1} \mathrm{H}-\mathrm{NMR}(500 \mathrm{MHz}, \mathrm{MeOD}) ; \delta_{\mathrm{H}} 0.97\left(2 \mathrm{H}, \mathrm{d}, J=6.2 \mathrm{~Hz}, \mathrm{H}-6^{\prime \prime \prime}\right), 1.66\left(3 \mathrm{H}, \mathrm{s}, \mathrm{H}-5^{\prime \prime}\right), 1.71(3 \mathrm{H}, \mathrm{s}$, H-4"), $3.06\left(1 \mathrm{H}, \mathrm{t}, J=11.0 \mathrm{~Hz}, \mathrm{H}-5^{\prime \prime \prime} \mathrm{b}\right), 3.22-3.03\left(1 \mathrm{H}, \mathrm{m}, \mathrm{H}-3^{\prime \prime \prime}\right), 3.22-3.17\left(1 \mathrm{H}, \mathrm{m}, \mathrm{H}-3^{\prime \prime \prime}\right), 3.33-3.26$ (2H, m, H-2'"'), 3.33-3.26 (2H, m, H-2"'"), 3.42-3.37 (2H, m, H-4"'"), $3.44\left(1 \mathrm{H}, \mathrm{dd}, J=8.3 \mathrm{~Hz}, \mathrm{H}-1^{\prime \prime}\right), 3.61$ $\left(1 \mathrm{H}, \mathrm{dd}, J=9.6,6.2 \mathrm{~Hz}, \mathrm{H}-5^{\prime \prime \prime}\right), 3.67\left(1 \mathrm{H}, \mathrm{dd}, J=5.4,11.5 \mathrm{~Hz}, \mathrm{H}-5^{\prime \prime \prime}{ }^{\prime \prime}\right), 3.82(1 \mathrm{H}, \mathrm{dd}, J=3.4,9.8 \mathrm{~Hz}$, H-4"' $\left.{ }^{\prime \prime \prime}\right), 3.86\left(3 \mathrm{H}, \mathrm{s}, \mathrm{H}-7^{\prime}\right), 4.30\left(1 \mathrm{H}, \mathrm{d}, J=7.63 \mathrm{~Hz}, \mathrm{H}-1^{\prime \prime \prime}\right), 5.19\left(1 \mathrm{H}, \mathrm{t}, J=6.87 \mathrm{~Hz}, \mathrm{H}-2^{\prime \prime}\right), 5.46(1 \mathrm{H}, \mathrm{s}$, $\left.\mathrm{H}-1^{\prime \prime \prime}\right), 6.26(1 \mathrm{H}, \mathrm{s}, \mathrm{H}-6), 7.11\left(2 \mathrm{H}, \mathrm{d}, J=8.9 \mathrm{~Hz}, \mathrm{H}-3^{\prime}\right.$ and $\left.\mathrm{H}-5^{\prime}\right), 7.87\left(2 \mathrm{H}, \mathrm{d}, J=8.9 \mathrm{~Hz}, \mathrm{H}-2^{\prime}\right.$ and $\left.\mathrm{H}-6^{\prime}\right)$.

\subsubsection{Koreanoside F (Compound 7)}

FABMS $m / z 543[\mathrm{M}]^{+}$; HRFABMS $m / z 543.1906$ (Calcd for $\mathrm{C}_{28} \mathrm{H}_{31} \mathrm{O}_{11}, 543.1788$ ); yellow powder; for ${ }^{1} \mathrm{H}$ and ${ }^{13} \mathrm{C}$-NMR data, see Table 1 .

\subsubsection{Koreanoside G (Compound 8)}

FABMS $m / z 529[\mathrm{M}]^{+}$; HRFABMS $m / z 529.1682$ (Calcd for $\mathrm{C}_{27} \mathrm{H}_{28} \mathrm{O}_{11}, 529.1632$ ); yellow powder; for ${ }^{1} \mathrm{H}$ and ${ }^{13} \mathrm{C}$-NMR data, see Table 1 .

\subsection{Bacterial Neuraminidase Inhibitory Activity Assay}

Neuraminidase from Clostridium perfringens (C. welchii) (EC 3.2.1.18) was evaluated as described previously with slight modification [21]. 4-Methylumbelliferyl- $N$-acetyl- $\alpha$-D-neuraminic acid sodium salt hydrate was used as the substrate. The fluorescence was measured using a UV-Vis spectrophotometer (Spectra Max M3, Molecular Devise, Sunnyvale, CA, USA) with a 96-well black immuno-microplate (SPL life science, Pocheon, Korea) at $37^{\circ} \mathrm{C}$ with an emission wavelength of $450 \mathrm{~nm}$ and an excitation wavelength of $365 \mathrm{~nm}$. All the samples were dissolved in DMSO at $10 \mathrm{mM}$ and diluted to the required concentration. First, $20 \mu \mathrm{l}$ of $1 \mathrm{mM}$ of an aqueous solution of the substrate $\left(K_{\mathrm{m}}=100 \mu \mathrm{M}\right)$ was mixed with $160 \mu \mathrm{l}$ of $50 \mathrm{mM}$ sodium acetate buffer ( $\mathrm{pH}$ 5.0). Then, $10 \mu \mathrm{l}$ of the inhibitors and $10 \mu \mathrm{l}$ of neuraminidase $(0.2$ units $/ \mathrm{mL})$ were added respectively to the mixture. Each assay was conducted as 3 separate replicates. The inhibitor concentration, leading to a $50 \%$ activity loss $\left(\mathrm{IC}_{50}\right)$, was obtained by the following equation: Activity $(\%)=100\left[1+\left([\mathrm{I}] / \mathrm{IC}_{50}\right)\right]$.

\subsection{Enzyme Kinetics and Progress Linear Determinations}

To determine the enzyme inhibition kinetics, an experiment was performed having different substrate and inhibitor concentration ranges. To find out each curve parameter, a nonlinear regression program was used for data analysis using Sigma Plot. Similarly, $K_{\mathrm{m}}$ and $V_{\max }$ were derived from the Lineweaver-Burk plot. Additionally, the $K_{\mathrm{i}}$ value was calculated from Dixon plots. The $K_{\mathrm{ik}}$ and $K_{\mathrm{iv}}$ rate constants were calculated according to Equations (1) and (2) proposed by Yang et al. [16].

$$
\begin{aligned}
& K_{\mathrm{m}}=K_{\mathrm{m} 0} \times\left(1+[\mathrm{I}] / K_{\mathrm{ik}}\right) \\
& V_{\mathrm{m}}=V_{\mathrm{m} 0} \times\left(1+[\mathrm{I}] / K_{\mathrm{iv}}\right)
\end{aligned}
$$




\subsection{Binding Affinity between Bacterial Neuraminidase and Compounds}

$180 \mu \mathrm{l}$ of $50 \mathrm{mM}$ sodium acetate buffer ( $\mathrm{pH}$ 5.0) with $10 \mu \mathrm{l}$ of $0.5 \mathrm{unit} / \mathrm{mL}$ neuraminidase from Clostridium perfringens were accurately added into the 96-well black immuno-plates; then, different $10 \mu \mathrm{l}$ concentrations $(15.6 \sim 250 \mu \mathrm{M})$ of inhibitor were added. The spectra for the fluorescent emissions were recorded from 300 to $400 \mathrm{~nm}$ with emission slits adjusted to $2.0 \mathrm{~nm}$, and the excitation was $260 \mathrm{~nm}$ using a spectrophotometer (Spectra Max M3). All the experiments were performed in triplicate. Fluorescence quenching is described by the Stern-Volmer equation.

$$
F_{0}-F=1+K_{\mathrm{SV}}[\mathrm{Q}]
$$

$F_{0}$ and $F$ are the fluorescence intensities in the absence and presence of quencher $(\mathrm{Q}) . K_{\mathrm{SV}}$ is the Stern-Volmer quenching constant $\left[\mathrm{IM}^{-1}\right]$. For static quenching, the relationship between the change in the fluorescence intensity and the concentration of quencher for the set of reaction can be described by the following equation.

$$
\log \left[\left(F_{0}-F\right) / F\right]=\log K_{\mathrm{A}}+n \log [\mathrm{Q}]_{\mathrm{f}}
$$

$\mathrm{Q}_{\mathrm{f}}$ is the concentration of free inhibitors; $n$ is the number of binding sites; and $K_{\mathrm{A}}$ is the binding constant. From the plots of linear Equation (4) obtained by $\log \left[\left(F_{0}-F\right) / F\right]$ versus $\log [Q]_{f}$, one can calculate the values of $K_{\mathrm{A}}$ and $n$. The value of $n$ approximates to one, indicating that only a single binding site exists in bacterial neuraminidase for inhibitors [22].

\subsection{Statistical Analysis}

All the experiments were conducted in triplicate. The results were subjected to variance analysis using Sigma Plot (version 10.0, Systat Software, Inc., San Jose, CA, USA). Differences were considered significant at $p<0.05$.

\section{Conclusions}

In conclusion, we have undertaken a thorough investigation of bacterial neuraminidase inhibition by E. koreanum Nakai, an important medicinal plant. The principal components were identified as prenylated flavonoids, including two new ones, named koreanoside F and koreanoside G. They showed mainly noncompetitive behavior that was demonstrated with the kinetic parameters $V_{\max }, K_{\mathrm{m}}, K_{\mathrm{ik}}$, and $K_{\mathrm{iv}}$. The binding affinities $\left(K_{\mathrm{SV}}\right)$ of the inhibitors were measured by a fluorescence quenching effect. In particular, the prenyl group on the flavonoids played a critical role in bacterial NA inhibition. The most active compound $\mathbf{1}\left(\mathrm{IC}_{50}=0.17 \mu \mathrm{M}\right)$ was 500 times more effective than its mother skeleton $\left(\mathrm{IC}_{50}=85.6 \mu \mathrm{M}\right)$. We are hopeful that prenylated flavonoids can be of use as a lead structure for neuraminidase inhibitors.

Supplementary Materials: The following are available online, Figures S1-S32: 1D, 2D-NMR of isolated compounds (1-8), Figure S33: Enzyme kinetic data of isolated compounds, Figure S34: Fluorescence quenching effect of isolated compounds.

Author Contributions: H.M.C. and Y.J.B. isolated compounds from E. koreanum. J.Y.K. and A.B. screened bacterial neuraminidase inhibitory activities. Z.P.L. and J.J. identified the structure of the isolated compounds. K.H.P. designed the overall research.

Funding: This work was done with research funds from the National Research Foundation of Korea (NRF) grant funded by the government of the Republic of Korea (MSIT) [2018R1A2B6001753] and the Next-Generation BioGreen 21 program, Rural Development Administration (SSAC, No. PJ01318601), Republic of Korea. The BK21 Plus program supported scholarships for students.

Conflicts of Interest: The authors declare no conflict of interest. 


\section{References}

1. Matrosovich, M.N.; Matrosovich, T.Y.; Gray, T.; Roberts, N.A.; Klenk, H.-D. Human and avian influenza viruses target different cell types in cultures of human airway epithelium. Proc. Natl. Acad. Sci. USA 2004, 10113, 4620-4624. [CrossRef] [PubMed]

2. Shinya, K.; Ebina, M.; Yamada, S.; Ono, M.; Kasai, N.; Kawaoka, Y. Influenza virus receptors in the human airway. Nature 2006, 56, 85-89. [CrossRef] [PubMed]

3. Couceiro, J.N.S.S.; Paulson, J.C.; Baum, L.G. Influenza virus strains selectively recognize sialyloligosaccharides on human respiratory epithelium; the role of the host cell in selection of hemagglutinin receptor specificity. Virus Res. 1993, 29, 155-165. [CrossRef]

4. Soong, G.; Muir, A.; Gomez, M.I.; Waks, J.; Reddy, B.; Planet, P.; Singh, P.K.; Kanetko, Y.; Wolfgang, M.C.; Hsiao, Y.S.; et al. Bacterial neuraminidase facilitates mucosal infection by participating in biofilm production. J. Clin. Invest. 2006, 116, 2297-2305. [CrossRef] [PubMed]

5. Chen, G.Y.; Chen, X.; King, S.; Cavassani, K.A.; Cheng, J.; Zheng, X.; Cao, H.; Yu, H.; Qu, J.; Fang, D.; et al. Amelioration of sepsis by inhibiting sialidase-mediated disruption of the CD24-SiglecG interaction. Nat. Biotechnol. 2011, 29, 428-435. [CrossRef] [PubMed]

6. Hiramatsu, K. Molecular Evolution of MRSA. Microbiol. Immunol. 1995, 39, 531-543. [CrossRef] [PubMed]

7. Ryu, H.W.; Curtis-Long, M.J.; Jung, S.; Jin, Y.M.; Cho, J.K.; Ryu, Y.B.; Lee, W.S.; Park, K.H. Xanthones with neuraminidase inhibitory activity from the seedcases of Garcinia mangostana. Bioorganic Med. Chem. 2010, 18, 6258-6264. [CrossRef] [PubMed]

8. Ryu, Y.B.; Curtis-Long, M.J.; Kim, J.H.; Jeong, S.H.; Yang, M.S.; Lee, K.W.; Lee, W.S.; Park, K.H. Pterocarpans and flavanones from Sophora flavescens displaying potent neuraminidase inhibition. Bioorganic Med. Chem. Lett. 2008, 18, 6046-6049. [CrossRef] [PubMed]

9. Lee, Y.; Ryu, Y.B.; Youn, H.S.; Cho, J.K.; Kim, Y.M.; Park, J.Y.; Lee, W.S.; Park, K.H.; Eom, S.H. Structural basis of sialidase in complex with geranylated flavonoids as potent natural inhibitors. Acta Crystallogr. Sect. D Biol. Crystallogr. 2014, 70, 1357-1365. [CrossRef] [PubMed]

10. Ma, H.; He, X.; Yang, Y.; Li, M.; Hao, D.; Jia, Z. The genus Epimedium: An ethnopharmacological and phytochemical review. J. Ethnopharmacol. 2011, 134, 519-541. [CrossRef] [PubMed]

11. Wu, J.-N. An illustrated Chinese Materia Medica; Oxford University Press, Inc.: New York, NY, USA, 1932; ISBN 9780195140170.

12. Eddouks, M. Handbook of Ethnopharmacology; Research Signpost: Trivandrum, India, 2008; ISBN 9788130802138.

13. Zhang, W.; Chen, H.; Wang, Z.; Lan, G.; Zhang, L. Comparative studies on antioxidant activities of extracts and fractions from the leaves and stem of Epimedium koreanum Nakai. J. Food Sci. Technol. 2013, 50, 1122-1129. [CrossRef] [PubMed]

14. Wu, L.; Du, Z.R.; Xu, A.L.; Yan, Z.; Xiao, H.H.; Wong, M.S.; Yao, X.S.; Chen, W.F. Neuroprotective effects of total flavonoid fraction of the Epimedium koreanum Nakai extract on dopaminergic neurons: In vivo and in vitro. Biomed. Pharmacother. 2017, 91, 656-663. [CrossRef] [PubMed]

15. Yang, X.; Du, Z.; Pu, J.; Zhao, H.; Chen, H.; Liu, Y.; Li, Z.; Cheng, Z.; Zhong, H.; Liao, F. Classification of difference between inhibition constants of an inhibitor to facilitate identifying the inhibition type. J. Enzyme Inhib. Med. Chem. 2013, 28, 205-213. [CrossRef] [PubMed]

16. Eftink, M.R.; Ghiron, C.A. Fluorescence quenching studies with proteins. Anal. Biochem. 1981, 114, $199-227$. [CrossRef]

17. Uddin, Z.; Song, Y.H.; Curtis-Long, M.J.; Kim, J.Y.; Yuk, H.J.; Park, K.H. Potent bacterial neuraminidase inhibitors, anthraquinone glucosides from Polygonum cuspidatum and their inhibitory mechanism. J. Ethnopharmacol. 2016, 193, 283-292. [CrossRef] [PubMed]

18. Wang, T.; Zhang, D.-W.; Zhang, J.-C.; Yang, M.-S.; Xiao, P.-G. Isolation and identification of flavonoids from Epimedium koreanum and their effects on proliferation of RAW 264.7 cell line. Chinese Tradit. Herb. Drugs 2006, 37, 1458-1462.

19. Li, J.Y.; Li, H.M.; Liu, D.; Chen, X.Q.; Chen, C.H.; Li, R.T. Three new acylated prenylflavonol glycosides from Epimedium koreanum. Phytochem. Lett. 2016, 17, 206-212. [CrossRef]

20. Li, H.M.; Zhou, C.; Chen, C.H.; Li, R.T.; Lee, K.H. Flavonoids isolated from heat-processed Epimedium koreanum and their anti-HIV-1 activities. Helv. Chim. Acta 2015, 98, 1177-1187. [CrossRef] 
21. Potier, M.; Mameli, L.; Bélisle, M.; Dallaire, L.; Melançon, S.B. Fluorometric assay of neuraminidase with a sodium (4-methylumbelliferyl- $\alpha-\mathrm{D}-\mathrm{N}$-acetylneuraminate) substrate. Anal. Biochem. 1979, 2697, 90362. [CrossRef]

22. Boaz, H.; Rollefson, G.K. The Quenching of Fluorescence. Deviations from the Stern-Volmer Law. J. Am. Chem. Soc. 1950, 72, 3435-3443. [CrossRef]

Sample Availability: Samples of the compounds are available from the authors.

(C) 2019 by the authors. Licensee MDPI, Basel, Switzerland. This article is an open access article distributed under the terms and conditions of the Creative Commons Attribution (CC BY) license (http://creativecommons.org/licenses/by/4.0/). 